\title{
The Administrative Board of Review of the European Central Bank: Experience After 2 Years
}

\author{
Concetta Brescia Morra ${ }^{1,2} \cdot$ René Smits $^{3}$. \\ Andrea Magliari ${ }^{4}$
}

(C) The Author(s) 2017. This article is an open access publication

\begin{abstract}
This article examines the administrative remedy provided by the Administrative Board of Review (ABoR) of the European Central Bank (ECB), as part of the broader issue of the right of defence of natural and legal persons vis-à-vis ECB supervisory decisions within the Single Supervisory Mechanism (SSM). After presenting an overview of the review panels established in the financial sector in the EU, the article describes the experience with the ABoR by analysing its composition, its mandate and scope of review, the main procedural aspects and the relationship with judicial proceedings before the European Court of Justice. Particular
\end{abstract}

\begin{abstract}
This article is based on the presentation René Smits gave at a workshop on The Single Supervisory Mechanism-Experience from the First Years of an Interplay with National Banking Supervision, held on 11 October 2016 in Florence, organised by the Law department of the European University Institute, and on a presentation by Concetta Brescia Morra, The experience and case law of the Board of Review of the SSM, at the conference Reflection on the design and implementation of the European Banking Union held on 16 September 2016 in Bologna, organized by the University of Bologna and the European Banking Institute (EBI). Andrea Magliari contributed with research and drafting as a third author. The views in this article are personal to the authors and may not be attributed to the Administrative Board of Review, the Single Supervisory Mechanism or the European Central Bank.

The cut-off date for the figures included in this contribution is 24 April 2017.
\end{abstract}

$\triangle$ René Smits

r.smits@uva.nl

Concetta Brescia Morra

bresciam@unisannio.it; cbresciamorra@luiss.it

Andrea Magliari

andrea.magliari@unitn.it

1 Faculty of Law, University of Sannio, Benevento, Italy

2 Libera Università Internazionale degli Studi Sociali (LUISS), Guido Carli, Rome, Italy

3 University of Amsterdam, Amsterdam, The Netherlands

4 University of Trento, Trento, Italy 
attention is given to the substantial issues dealt with by the ABoR in its Opinions and to some of the major challenges faced in the first 2 years of practice. Among them is the assessment of the correct application of national laws implementing EU legislation by the ECB. The paper identifies two aspects giving particular cause for concern and requiring legislative reforms: (1) the assessment of the suitability of the members of management bodies (fit and proper assessment) and (2) the inclusion of bank holding companies within the scope of banking supervision.

Keywords Prudential supervision · Administrative review · European Central Bank · Banking union · Fit and proper · Bank holding supervision · Financial sector review panels

\section{Introduction}

The establishment of the Single Supervisory Mechanism (SSM) in the EU represents a milestone in the European integration process. Council Regulation No. 1024/2013 (the SSM Regulation) ${ }^{1}$ confers on the European Central Bank (ECB) a wide set of tasks and powers related to the prudential supervision of credit institutions, financial holding companies and mixed financial holding companies established in the Euro Area, with the main purpose of enhancing the safety and soundness of credit institutions within the Eurozone and safeguarding the financial stability in the EU and in each Member State. ${ }^{2}$ To this end, the ECB has been empowered-inter alia - to grant and withdraw the banking license, to assess notifications of the acquisition of qualifying holdings in credit institutions, to ensure compliance with prudential requirements set out in the relevant EU law and to carry out supervisory reviews, including stress tests. ${ }^{3}$ Moreover, the ECB may impose early intervention measures and administrative pecuniary sanctions on the supervised entities.

In order to carry out its tasks, the ECB applies not only the relevant Union law (the 'Single Rulebook'), ${ }^{4}$ but also national legislation transposing EU

\footnotetext{
${ }^{1}$ Council Regulation (EU) No. 1024/2013 of 15 October 2013 conferring specific tasks on the European Central Bank concerning policies relating to the prudential supervision of credit institutions. See Busch and Ferrarini (2015); Chiti and Vesperini (2015); Wymeersch (2014), p 1; Teixeira (2014), p 568; Brescia Morra (2014), pp 465 et seq.; D’Ambrosio (2015); Gortsos (2015); Lo Schiavo (2014), pp 110 et seq.; Ter Kuile et al. (2015), pp 155-190; Ferran and Babis (2013).

2 On the powers of the ECB under Art. 127(6) for the purposes of financial stability, see in particular Lastra (2012), pp 1274 et seq.; Smits (2005), pp 199 et seq.

3 Art. 4(1) SSM Regulation.

4 The term Single Rulebook was coined in 2009 by the European Council in order to refer to a unified regulatory framework for the EU financial sector that would complete the single market in financial services. The Single Rulebook aims to provide a single set of harmonised prudential rules which institutions throughout the EU must respect. The Single Rulebook is currently composed of the Capital Requirements Regulation (CRR) and the Capital Requirements Directive (CRD IV), the Bank Recovery and Resolution Directive (BRRD), the Deposit Guarantee Schemes Directive (DGSD), and the corresponding regulatory and implementing technical standards developed by the European Banking Authority (EBA) and adopted by the European Commission (RTS and ITS), as well as the EBA Guidelines and related Q\&As, available at https://www.eba.europa.eu/regulation-andpolicy/single-rulebook/interactive-single-rulebook (accessed 24 April 2017). On the Single Rulebook in the framework of the SSM, see in particular Lefterov (2015); Babis (2015), pp 779-803.
} 
directives. ${ }^{5}$ Moreover, Article 9(1), second sub-paragraph, of the SSM Regulation entrusts the ECB with all the powers and obligations that EU law confers on the public authorities empowered by national law to supervise institutions (competent authorities $^{6}$ ) and designated authorities. ${ }^{7}$

The institutional framework underpinning the new supervisory mechanism is rather complex and presents a number of original features. Among them, little attention has been paid so far $^{8}$ to the review mechanism established by Article 24 of the SSM Regulation which purpose it is to carry out an internal administrative review of the decisions taken by the ECB within the framework of the SSM. This paper intends to investigate the administrative remedy provided by the Administrative Board of Review (ABoR) of the ECB, as part of the broader issue of the right of defense of natural and legal persons vis-à-vis the new European supervisor. ${ }^{9}$

The article is structured as follows: Sect. 2 presents an overview of the review panels established in the financial sector in the EU. Section 3 describes the experience with the ABoR and analyses its composition, its mandate and scope of review, the rules of procedure and the functioning as set out in the ECB Decision of 14 April 2014 (the ABoR Decision). ${ }^{10}$ Section 4 gives an overview of the main issues dealt with by the $\mathrm{ABoR}$ in its case law and highlights some of the major challenges. Section 5 concludes.

\section{Review Panels in the Financial Sector: An Overview}

The establishment of an internal board in charge of carrying out an administrative review of the acts adopted by EU bodies is not a novelty itself. ${ }^{11}$ Indeed, within the European legal framework, review panels providing quasi-judicial review have been introduced in a number of European agencies (e.g. the Board of Appeal of the European Chemical Agency (ECHA), ${ }^{12}$ the Boards of Appeal of the Office for Harmonization in the Internal Market (OHIM), ${ }^{13}$ and the Board of Appeal of the

\footnotetext{
5 Art. 4(3) SSM Regulation.

6 According to Art. 2, point (2) of the SSM Regulation, 'national competent authority' means a national competent authority designated by a participating Member State in accordance with Regulation (EU) No. 575/2013 of the European Parliament and of the Council of 26 June 2013 on prudential requirements for credit institutions and investment firms (1) and Directive 2013/36/EU.

7 Pursuant to point (7) of the same Art. 2, 'national designated authority' means a designated authority of a participating Member State, within the meaning of the relevant Union law.

8 With relevant exceptions. See, in particular, Brescia Morra (2016), pp 109-132; Lackhoff and Meissner (2015), p 285.

9 See Arons (2015).

${ }^{10}$ Decision of the European Central Bank of 14 April 2014 concerning the establishment of an Administrative Board of Review and its operating rules (ECB/2014/16).

11 An overview of the alternative dispute resolution mechanisms in the EU is provided by Magiera and Weiß (2014), p 489. See also De Lucia (2014), p 277; Chirulli and De Lucia (2015), pp 832-857.

12 See Council Regulation (EC) No. 1907/2006 concerning the registration, evaluation, authorization and restriction of chemicals (REACH) establishing a European Chemical Agency. In the legal literature, see Bronckers and Van Gerven (2009), p 1823; Navin-Jones (2015), p 143; Bolzonello (2016), pp 569-581.

13 Council Regulation (EC) No. 207/2009 on the Community trade mark.
} 
Agency for the Cooperation of Energy Regulators $\left(\mathrm{ACER}^{14}\right)$. In recent years, the unprecedented shift of responsibilities to supranational bodies and institutions triggered by the financial crisis has been complemented by the creation of review mechanisms entrusted to independent panels of administrative nature. In the financial sector, the first example of administrative review is the Joint Board of Appeal of the three European supervisory authorities (EBA, ESMA, EIOPA, together referred to as the European Supervisory Authorities, ESAs), established pursuant to Articles 58-61 of their respective founding regulations. ${ }^{15}$ The second example is, as already anticipated, the Administrative Board of Review of the ECB, in the framework of the SSM. The third is the Appeal Panel of the Single Resolution Board (SRB), in the framework of the Single Resolution Mechanism (SRM), established in accordance to Article 85 of Regulation (EU) No 806/2014 ${ }^{16}$ (the SRM Regulation). The three review mechanisms present many similarities, but also some significant distinctive features.

The founding regulations provide that, from a structural perspective, the three boards are independent administrative bodies entrusted with the task of reviewing the decisions adopted by the respective authority. These bodies shall act independently and in the public interest ${ }^{17}$ and shall have sufficient resources and expertise to perform their tasks. ${ }^{18}$ Moreover, from a functional perspective, they represent an important tool aimed at fostering the protection of natural persons and legal entities, in line with the due process requirements, while at the same time enhancing the accountability regime of the respective administrative authorities.

However, one may argue that the three tools show different approaches to legal challenges. Indeed, while the Joint Board of Appeal and the Appeal Panel are 'appeal bodies' issuing a 'decision' which is legally binding for the respective administrative authority, the ABoR carries out an 'internal review' of the ECB decisions and adopts a non-binding 'opinion' addressed to the Supervisory Board of the ECB. The first two appeal bodies may either confirm the decision taken by the competent authority, or remit the case to the latter which, in turn, is bound by the decision of the appeal body. Conversely, the ABoR can only propose to the Supervisory Board to approve a new draft decision abrogating the initial decision, replacing it with a decision of identical content, or with an amended one. As will be

\footnotetext{
${ }^{14}$ Regulation (EC) No. 713/2009 of the European Parliament and of the Council of 13 July 2009 establishing an Agency for the Cooperation of Energy Regulators.

15 Arts. 58-61 of Regulation (EU) No. 1093/2010, of 24 November 2010, establishing the European Banking Authority (EBA), Regulation (EU) No. 1094/2010, of 24 November 2010, establishing the European Insurance and Occupational Pensions Authority (EIOPA) and Regulation (EU) No. 1095/2010, of 24 November 2010, establishing the European Securities and Markets Authority (ESMA). On the Joint Board of Appeal, see Lamandini (2014), pp 290-294; Witte (2015), p 226; Blair (2013), p 165; Loosveld (2013), p 9.

${ }^{16}$ Regulation (EU) No. 806/2014 of 15 July 2014 establishing uniform rules and a uniform procedure for the resolution of credit institutions and certain investment firms in the framework of a Single Resolution Mechanism and a Single Resolution Fund and amending Regulation (EU) No. 1093/2010.

17 See Art. 59(6) EBA/ESMA/EIOPA Regulations, Art. 24(4) SSM Regulation and Art. 85(5) SRM Regulation.

18 See Art. 58(2) EBA/ESMA/EIOPA Regulations, Art. 24(2) SSM Regulation and Art. 85(2) SRM Regulation.
} 
further examined in the next paragraphs, the Supervisory Board has to take the ABoR opinion into account before submitting a new draft decision to the Governing Council, for the adoption under the non-objection procedure, following the decision-making process set out in Article 26 of the SSM Regulation. ${ }^{19}$ Moreover, while the use of the term 'appeal' highlights the intent to refer to a 'quasi-judicial' body with adjudicative function, ${ }^{20}$ the name of the ABoR illustrates the administrative nature of the panel which cannot be compared, from a structural and functional perspective, to a court or a tribunal.

Secondly, while the SSM Regulation makes it clear that the scope of review of the ABoR shall pertain to the procedural and substantive conformity of the ECB decision to the applicable legal framework, in the case of the Joint Board of Appeal and the Appeal Panel the relevant regulations do not clearly specify whether the scope of the review is limited to the legality of the contested decision or is extended to its merit. The original Commission proposal ${ }^{21}$ conferred on the Joint Board of Appeal 'any power which lies within the competence of the Authority', thus granting it the power to take new substantive decisions. However, the final version adopted by the Parliament and the Council no longer contains this provision and leaves the Joint Board of Appeal only with the option of confirming the contested decision or remitting the case before the relevant authority. Therefore, when taking into consideration the structure of the review process, with its lack of explicit substitutive powers conferred on the appeal panel, it is argued that the review is limited to questions of legality ${ }^{22}$ and does not encompass a different evaluation of the opportunity of the discretionary choices taken by the authorities.

Another significant difference concerns the allocation of the power to suspend the effects of the contested act. In principle, the simple submission of the request for appeal/review does not have automatic suspensory effect. However whereas the Joint Board of Appeal and the Appeal Panel may directly suspend the application of the contested decision if they consider that circumstances so require, ${ }^{23}$ the ABoR does not have such power, the power being entrusted only to the Governing Council of the ECB, upon a proposal from the ABoR, after having heard the opinion of the Supervisory Board, as appropriate. It is also noteworthy that only the rules of

\footnotetext{
19 Pursuant to Art. 26(8) of the SSM regulation, the Supervisory Board shall carry out preparatory works regarding the supervisory tasks conferred on the ECB and propose to the Governing Council of the ECB complete draft decisions to be adopted by the latter. A draft decision shall be deemed adopted unless the Governing Council objects within a period to be defined in the procedure mentioned above but not exceeding a maximum period of ten working days. If the Governing Council objects to a draft decision, it shall state the reasons for doing so in writing, in particular stating monetary policy concerns. See also Arts. 13g, 13h and 13i of Decision of the European Central Bank of 19 February 2004, adopting the Rules of Procedure of the ECB, as amended by Decision ECB/2014/1 of 22 January 2014.

20 Chirulli and De Lucia (2015).

21 EU Commission, Proposal for a Regulation of the European Parliament and of the Council, establishing a European Banking Authority (COM(2009) 501 final).

22 See Witte (2015), p 20; Lamandini (2014); Blair (2013). A different view is expressed by Wymeersch (2012), p 232; Chirulli and De Lucia (2015), p 846 who claim that the boards of appeal of the ESAs and of the SRM 'can review the legal and technical correctness as to the merits of the first decision in the light of the specific points raised by the claimants'.
}

23 Art. 60(3) EBA/ESMA/EIOPA Regulations, Art. 85(6) SRM Regulation. 
procedure of the $\mathrm{ABoR}$ indicate the grounds according to which the suspension may be granted to the applicant. Pursuant to Article 9 of the ABoR Decision, the contested decision may be suspended provided the request for review is admissible, not obviously unfounded and that the immediate application of the contested decision may cause irreparable damage. ${ }^{24}$ In this respect one may argue that these conditions mirror the requirements set out for the suspensive order before judicial bodies (prima facie case or fumus boni juris and periculum in mora); by contrast the Joint Board of Appeal and the Appeal Panel seem to enjoy a broader discretion in the evaluation of the relevant circumstances, as they are not limited by any explicit legal criterion.

Lastly, a further distinction pertains to the relationship between the administrative and the judicial remedy. Indeed, while in principle the availability of an administrative internal review cannot per se prevent the affected person from bringing an action before the Court of Justice, the founding regulations of European agencies often stipulate that the prior recourse to the appeal body constitutes a condition of admissibility of the request for judicial review. ${ }^{25}$ Along these lines, Article 61(1) of the ESAs Regulations and Article 86(1) of the SRM Regulation provide that judicial proceedings may be brought before the Court of Justice contesting a decision taken either by the appeal body or, in cases where there is no such right of appeal, ${ }^{26}$ by the Authority. Although the formulation of these provisions is not entirely clear, ${ }^{27}$ it is submitted that whenever it is possible to bring an appeal before the review panel the party concerned must preemptively exhaust the administrative remedy before filing an action for annulment before the General Court. ${ }^{28}$ Subsequently, if the appeal body confirms the contested decision, judicial proceedings can be brought directly against the decision taken by the appeal body whereas if the appeal body remits the case before the relevant Authority, the party concerned can challenge the new decision adopted by the Authority only before the Court of Justice. In both cases, the action can be brought both on points of law and on questions of fact.

On the contrary, the submission of a request for review of an ECB decision before the ABoR is purely optional, the party affected by the decision being entitled either to seek internal review by the ABoR before appealing to the ECJ or to immediately file an action for annulment before the Court of Justice, under Article 263 TFEU. If the affected party takes the ABoR route, it can subsequently bring the ECB's decision adopted, or confirmed after the ABoR review, before the General

\footnotetext{
24 Art. 24(8) SSM Regulation and Art. 9 ECB Decision 2014/16.

25 See, for instance, Art. 50 of Regulation (EC) No. 216/2008, establishing a European Aviation Safety Agency (EASA), setting out that 'Actions for the annulment of decisions of the Agency [...] may be brought before the Court of Justice of the European Communities only after all appeal procedures within the Agency have been exhausted'.

${ }^{26}$ Under Art. 85(3) of the SRM Regulation not every decision adopted by the Single Resolution Board can be appealed before the Appeal Panel, but only 'a decision of the Board referred to in Article 10(10), Article 11, Article 12(1), Articles 38 to 41, Article 65(3), Article 71 and Article 90(3) which is addressed to that person, or which is of direct and individual concern to that person'.

27 See, in particular, Lamandini (2014), p 293.

28 Art. 61(1) EBA/ESMA/EIOPA Regulations and Art. 86(1) SRM Regulation.
} 
Court. The ABoR Opinion as such cannot be challenged: it does not constitute a justiciable legal act.

The highlighted differences could be explained by reference to the different architectural frameworks underpinning the establishment of the respective administrative authorities. Indeed, while the ABoR is an independent internal review mechanism of an EU institution, whose ultimate decision-making bodies are established in the Treaties, the Joint Board of Appeal and the SRB Appeal Panel are appeal bodies of European agencies, established by EU secondary law, on the basis of Article 114 TFEU.

In other words, in order to understand the peculiar position of the ABoR it is important to consider that its establishment has been framed within the governance structure of the ECB, as designed by the Treaties and by the Statute of the ESCB and of the ECB, as well as in the framework of the peculiar decision-making process introduced by the SSM Regulation. Accordingly, the non-binding nature of the ABoR's opinion can also be explained by the necessity to respect the primary law laying down that the Governing Council and the Executive Board are the only decision-making bodies of the ECB.

Moreover, Article 263(5) TFEU, which provides that 'acts setting up bodies, offices and agencies of the Union may lay down specific conditions and arrangements concerning actions brought by natural or legal persons against acts of these bodies, offices or agencies intended to produce legal effects in relation to them', only applies to the Joint Board of Appeal and the SRB Appeal Panel, but not the ABoR, as an internal body of an EU institution.

Such differences in the physiognomy of the administrative remedies are also reflected in a different outcome of the review procedures. Opinions of the ABoR are only notified to the applicant together with the new decision adopted by the Governing Council. The proceedings of the ABoR are confidential and its opinions are not published, unless the Governing Council authorises the President to make the outcome of such proceedings public. ${ }^{29}$ By contrast, the Joint Board of Appeal publishes its decisions in full on the agencies' website ${ }^{30}$ and the Appeal Panel publishes only an extract of the grounds of its decision, taking into account the need to protect the confidentiality of sensitive information. ${ }^{31}$ Furthermore, as mentioned above, only the decisions of the Joint Board of Appeal and the SRB Appeal Panel may end up in court and may be subject to an action for annulment, whereas the opinions issued by the ABoR cannot be directly challenged before the ECJ.

In conclusion, the Board of Appeal of the ESAs and the Appeal Panel, having an adjudicative function, can be considered quasi-judicial bodies while the ABoR is an organ that carries out an internal administrative review of the decisions of the ECB in the supervisory field.

\footnotetext{
29 Art. 22, ECB Decision 2014/16.

30 Art. 60(7) EBA/ESMA/EIOPA Regulations and Art. 24 Board of Appeal of the European Supervisory Authorities Rules of Procedure.

31 Art. 24, Appeal Panel of the Single Resolution Board Rules of Procedure.
} 


\section{The Experience with the ABoR}

\subsection{Figures on the First 2 Years}

Within the SSM, the ECB is directly competent for the ongoing supervision of significant institutions ${ }^{32}$ established in the Eurozone, as well as for granting and withdrawing banking licenses and assessing the acquisition of qualifying holdings for all Euro Area credit institutions, irrespective of whether or not they are significant. This means that the ECB adopts a high number of individual decisions addressed to the supervised entities which may potentially affect their legal position. So far, 20 proceedings, ${ }^{33}$ coming from nine Member States, have been brought before the ABoR. ${ }^{34}$ In 15 cases, the $\mathrm{ABoR}$ has completed its internal review and issued an opinion, one proceeding is still pending, while in the other four cases the application has been withdrawn before the ABoR delivered an opinion. In these cases, as revealed by the ECB Annual Report 2015, 'the Board, including its Secretariat, contributed to the resolution of issues to the satisfaction of both the applicant(s) and the ECB, by playing a mediation role between the ECB and the applicant(s), ${ }^{35}$ As a result of the review process, only few cases ${ }^{36}$ have been brought before the European Court of Justice, thereby confirming that the administrative review also pursues procedural economy purposes, ${ }^{37}$ in addition to its main function of protecting of individual rights.

\subsection{Composition: Competence, Professional Expertise and Independence}

In order to understand the concrete functioning of the board of review and its role within the decision-making process of the $\mathrm{ECB}$, it is essential to first examine its composition and the independence requirements set up by the SSM Regulation. The

\footnotetext{
32 Art. 6(4) SSM Regulation.

33 ECB Annual Report 2016, p 56.

34 It is interesting to note that since its establishment the Joint Board of Appeal of the ESAs has decided only six cases, one of which has been brought before the Courts (see judgment of the General Court, 9 September 2015, SV Capital OÜ v. European Banking Authority, case T-660/14, now appealed before the ECJ, C-577/15 P). The Appeal Panel of the SRB has so far decided 14 cases, mostly related to the annual contributions to the Single Resolution Fund claimed by the Single Resolution Board and declared not admissible under Art. 85(3) of the SRM Regulation.

35 ECB Annual Report 2015, p 14.

36 See, for instance, the action brought on 12 March 2015 before the General Court Landeskreditbank Baden-Württemberg v. ECB (Case T-122/15), where the applicant contested the ECB decision classifying the supervised entity as a less significant entity on grounds of particular circumstances according to Art. 6(4) of the SSM Regulation (EU) in conjunction with Art. 70(1) of the ECB Regulation (EU) No. $468 / 2014$.

37 See Recital 64 of the SSM Regulation, stating that the ECB should establish an Administrative Board of Review 'for reasons of procedural economy'. See, in particular, Brescia Morra (2016), p 122.
} 
ABoR is composed of five members and two alternates ${ }^{38}$ which are appointed by the ECB for a term of 5 years, renewable only once. In particular, following a public call for expressions of interest published in the Official Journal of the EU, the Executive Board, after hearing the Supervisory Board, submits the nominations to the Governing Council which formally appoints the members of the ABoR. The members have the duty to act independently and in the public interest, and cannot be bound by any instructions. For that purpose, they submit a public declaration of commitments and a public declaration of interests, which indicate any direct or indirect interest which might be considered prejudicial to their independence, or the absence of any such interest. Moreover, Article 24 of the SSM Regulation establishes an incompatibility regime for the $\mathrm{ABoR}$ members and provides that they cannot be concurrently staff of the ECB, as well as current staff of competent authorities or other national or Union institutions, bodies, offices or agencies that are involved in tasks related to the ECB within the SSM. In addition, when a member is in a conflict of interest situation, arising from a private or personal interest which may influence, or appear to influence, his/her impartiality and objectivity, this member is to be replaced by one of the alternate members.

In order to further strengthen the independence of judgement of the body, the SSM Regulation requires the members to be of high repute and to have relevant knowledge and professional experience, including supervisory experience, in the fields of banking or other financial services. The appointment of the board's members and the alternates is to be conducted so as to ensure, to the extent possible, the respect of the principles of geographical and gender balance, as well as experience and qualification.

\subsection{Scope of Review}

The ABoR's scope of review is defined by Article 24 of the SSM Regulation which provides that any natural or legal person may request a review of a decision taken by the ECB in the exercise of the powers conferred on it by the SSM Regulation, and which is either addressed to that person, or is of a direct and individual concern to that person. This provision mirrors the locus standi conditions set out in Article 263(4) TFEU for the action for annulment before the Court of Justice. Despite the structural differences between the two procedures, it is submitted that the ABoR should interpret and apply the admissibility requirements in light of the relevant case law of the ECJ. ${ }^{39}$ Accordingly, if the applicant is not the addressee of the contested decision, the ABoR should apply the scrutiny test developed by the Court of Justice, entailing an assessment of whether the contested act itself affects the

\footnotetext{
38 The Administrative Board of Review is composed of five members: Jean-Paul Redouin (Chair), Concetta Brescia Morra (Vice-Chair), F. Javier Arístegui Yáñez, André Camilleri and Edgar Meister; and two alternates: René Smits and Kaarlo Jännäri (until 6 November 2015)/Ivan Šramko (since 3 February 2016). According to Art. 3(3) of the ABoR Decision, the two alternates shall temporarily replace the members of the Administrative Board in case of temporary incapacity, death, resignation or removal from office or if, in the context of a particular request for review, there are justified reasons for serious concern as to the existence of a conflict of interest.

39 See, in particular, Witte (2015), pp 1-37; Brescia Morra (2016), pp 117-118.
} 
situation of the individual and does not require any implementing measure, and whether that decision affects the applicant by reason of certain peculiar attributes or by reason of factual circumstances in which they are differentiated from all other persons. ${ }^{40}$ In addition to the standing requirements, the applicant has to demonstrate a present and vested interest in bringing proceedings before the $\mathrm{ABOR}$, meaning that it must show that it would benefit from a contested act being annulled as a result of its request for review.

Differently from the Joint Board of Appeal of the ESAs and from the Appeal Panel of the SRB, national competent authorities forming part of the SSM cannot file a request for review before the $\mathrm{ABoR}$.

As for the material scope of review, pursuant to Article 24(1) of the SSM Regulation, the ABoR is empowered to review 'decisions taken by the ECB in the exercise of the powers conferred on it' by the SSM regulation. One relevant question is whether the term 'decision' has to be understood in a formal way, meaning that only legal acts set out in Article 132(1), second indent, of the TFEU qualify as a decision, or in a substantial one, thus reflecting the interpretation of the ECJ according to which any measure which definitively determines the position of the authority upon the conclusion of an administrative procedure, and which is intended to have binding legal effects capable of affecting the interests of the applicant is open to challenge. ${ }^{41}$ A broader understanding of the scope of review is favored, as it appears more in line with the material interpretation applied by the courts, as well as with the fundamental principle of rule of law according to which any act of Union law capable of having legal effect can be reviewed. ${ }^{42}$ Accordingly, the ABoR should assess whether the contested act is capable of having legal effects vis-à-vis its addressees, irrespective of its legal form. Therefore, in principle, internal documents and acts of a preparatory nature, like for instance intermediate acts in a multi-step procedure, are not directly challengeable before the ABoR.

As for the extent of the review, Article 24 of the SSM Regulation specifies that the ABoR carries out an internal administrative review pertaining to 'the procedural and substantive conformity with this Regulation'. One may argue that the scope of the review is not limited to the conformity of the contested act with the SSM Regulation stricto sensu, but instead has to be understood as a broader reference to

\footnotetext{
${ }^{40}$ See the leading case Plaumann \& Co $v$. Commission, Case 25/62. An interesting issue is the locus standi of the shareholders of a credit institution. The case law of the ECJ is consistent in excluding the admissibility of an action for annulment brought by the shareholders of a company in all the cases in which the applicant does not have an interest in bringing proceedings which is separate from that possessed by an undertaking which is concerned by a European Union measure. Otherwise, in order to defend its interests in relation to that measure, the only remedy lies in the exercise of its rights as a member of the undertaking which itself has a right of action (para. 31, Case T-499/12, HSH Investment Holdings $v$. Commission).

41 See e.g. C-57/95, para. 7; C-370/07, para. 42; T-496/11, United Kingdom v. ECB, para. 51.

42 See, in particular, C-294/83, Les Verts v. European Parliament, para. 23, where the ECJ held that 'the European Economic Community is a Community based on the rule of law, inasmuch as neither its Member States nor its institutions can avoid a review of the question whether the measures adopted by them are in conformity with the basic constitutional charter, the Treaty'. See also C-11/00, Commission $v$. European Central Bank (OLAF case).
} 
all the applicable substantial and procedural law, as referred thereto. ${ }^{43}$ This means that, by virtue of Article 4(3) of the SSM Regulation, the ABoR will be confronted with the assessment of the substantive conformity of the ECB decisions not only with the EU legislation, but also with national laws implementing EU directives. As the next section clearly demonstrates, this is a novel situation and represents one of the biggest challenges for the ECB within the new integrated system of banking supervision.

Moreover, the board verifies whether the relevant procedural rules were fully respected. Due process guarantees are set out in detail in the ECB Regulation No. $468 / 2014^{44}$ (the SSM Framework Regulation). This Regulation encompasses the right of the parties to an ECB supervisory procedure to be granted the opportunity of commenting in writing on the facts, objections and legal grounds relevant to an ECB supervisory decision which would adversely affect their rights (right to be heard), ${ }^{45}$ the right to have access to the ECB's file, and the right to receive an accurately motivated decision, containing all the material facts and legal reasons on which the ECB supervisory decision has been based. It can be also argued that in the assessment of the procedural legality of the decision, the ABoR also checks the compliance with the general principles of EU law, as enshrined in the case law of the ECJ and recalled by the SSM Regulation. ${ }^{46}$ Among them, of particular relevance, is the correct application of the principles of equal treatment, nondiscrimination and proportionality. ${ }^{47}$

However, the SSM Regulation makes it clear that the administrative review shall respect 'the margin of discretion left to the ECB to decide on the opportunity to take those decisions'. ${ }^{48}$ In other words, the internal review is limited to the legality of the contested decision and cannot question its merit. Moreover, as in court proceedings, when the decision taken by the ECB involves a broad margin of discretion or a 'complicated economic assessment', it is submitted that also the review of the ABoR is confined to a 'limited standard of review'. Accordingly, the board's review is limited as to whether the due process requirements were complied with and, in particular, whether the statement of reasons was sufficient, whether the facts were correctly reproduced and whether there was any manifest error in the assessment,

\footnotetext{
43 Contra, see Wymeersch (2014), p 55.

44 Regulation (EU) No. 468/2014 of the European Central Bank of 16 April 2014 establishing the framework for cooperation within the Single Supervisory Mechanism between the European Central Bank and national competent authorities and with national designated authorities (ECB/2014/17).

45 Art. 22 of the SSM Regulation and Art. 31 of the SSM Framework Regulation.

46 Recitals 30, 58, 59, 81, 86.

47 On the application of these principles to the SSM, see in particular Lamandini et al. (2015).

48 Recital 64 of the SSM Regulation.
} 
and whether the decision is manifestly disproportionate or vitiated by a misuse of powers. $^{49}$

\subsection{Procedural Rules}

The review procedure can be divided in three phases $^{50}$ : (a) the preparatory phase, which includes the assessment of the admissibility of the request, (b) the examination phase, which may also entail an oral hearing and the collection of the relevant evidence, and (c) the deliberative phase, ending with the adoption of the opinion and its submission to the Supervisory Board.

As for the first phase, the review process is triggered by a written request submitted by a natural or legal person to the Secretary of the Administrative Board ${ }^{51}$ within 1 month of the date of notification of the decision or, in the absence thereof, of the day on which it came to the knowledge of the applicant. Despite a certain margin of flexibility, the ABoR assesses the admissibility of the application before examining whether the request is legally founded. If the request is held inadmissible wholly or in part, the assessment is recorded in the opinion and submitted to the Supervisory Board. If the request is admissible, the ABoR may propose to the Governing Council to suspend the effects of the contested decision, subject to the conditions mentioned above. It is worth noting that the power to suspend the decision is granted to the same body that shortly before adopted the contested decision, not exercising its power to object in accordance with Article 26(8) of the SSM Regulation.

In the second phase, the ABoR examines whether the substantial and procedural grounds raised by the applicant are well-founded. Pursuant to Article 10 of the ABoR Decision, ${ }^{52}$ establishing the Rules of procedures of the board, the internal review is limited to the examination of the grounds set forth in the notice of review and the ABoR cannot raise ex officio new grounds for review or complement the submissions filed by the applicant. In this respect, the ABoR acts similarly to a Court within the review of legality. Quite interestingly, however, the Supervisory

49 See, ex multis, the ECJ judgment in Telefonica and Telefonica de Espaňa v. Commission, C-295/12 P, para. 54, affirming that 'the Court of Justice has already stated that, whilst, in areas giving rise to complex economic assessments, the Commission has a margin of discretion with regard to economic matters, that does not mean that the EU judicature must refrain from reviewing the Commission's interpretation of information of an economic nature. The EU judicature must, among other things, not only establish whether the evidence put forward is factually accurate, reliable and consistent, but must also determine whether that evidence contains all the relevant data that must be taken into consideration in appraising a complex situation and whether it is capable of substantiating the conclusions drawn from it (Judgment in Commission v. Tetra Laval, C-12/03 P, EU:C:2005:87, para 39; Judgment in Chalkor v. Commission, C-386/10 P, EU:C:2011:815, para 54; and Judgment in Otis and Others, C-199/11, EU:C:2012:684, paragraph 59)'. On the evolution of the standard of review of the ECJ in competition law cases, see Kalintiri (2016), pp 1283 et seq. It is, however, yet to be seen to what extent the ECJ will apply the same approach vis-à-vis the 'complex economic evaluations' carried out by the ECB within the SSM.

50 Alternates do not take place in the examination and deliberation stages of the proceedings.

51 According to Art. 6 of the ABoR Decision, the Secretary of the Supervisory Board shall act as Secretary of the Administrative Board.

52 Decision of the European Central Bank of 14 April 2014 concerning the establishment of an Administrative Board of Review and its operating rules (ECB/2014/16). 
Board, after the review of the ABoR, may also take other elements into account when preparing its proposal for a new draft decision, thus acting in the pursuit of the general objectives entrusted to it by the SSM Regulation. This provision shows quite clearly the different nature and function of the two bodies within the decisionmaking process designed by the SSM Regulation.

In this phase, the ABoR collects and analyses all the relevant information for its final deliberation. In particular, in order to carry out an efficient conduct of the review, the Chair may give directions to the parties, including directions to produce documents or provide information. ${ }^{53}$ Moreover, the ABoR may call for an oral hearing ${ }^{54}$ where it considers it necessary for the fair evaluation of the case. It is important to highlight that the oral hearing is normally scheduled by the board as it represents a fundamental step in the review process. Indeed, the hearing is an important source of information for the board itself; it provides the applicant with the opportunity to present its view and to make oral representations before an independent panel, to hear the reasons of the ECB and to have a direct confrontation with it. The hearing is also essential for the ECB which has the possibility to provide a more extensive reasoning of the contested decision, to achieve a different evaluation of its conduct or even to reconsider its discretionary choices. The hearing is held at the ECB's premises in Frankfurt with the applicant (or its legal representative) and the ECB staff on different sides of the table, and is not open to third parties, thus confirming the confidential nature of the ABoR proceedings.

Another tool ensuring the right of defence of the parties is the possibility to request to the $\mathrm{ABoR}$ the permission to adduce witness or expert evidence in the form of a written statement or to call a witness or expert who has given a written statement to give oral evidence at the hearing. ${ }^{55}$ In these cases, the applicant is entitled to crossexamine the witnesses or experts when the latter has been called on by the ECB. However, the ABoR Decision makes it clear that such permission can only be given if the panel considers it necessary for the just determination of the review.

Finally, Article 6(3) of the ABoR Decision sets out that 'the ECB shall provide the Administrative Board with appropriate support including legal expertise to assist in the assessment of the exercise of the powers of the ECB'. This provision must be read in conjunction with the independence status granted to the board and with Article 24(2) of the SSM Regulation which stipulates that the ABoR 'shall have sufficient resources and expertise to assess the exercise of the powers of the ECB'. Accordingly, it is argued that the ABoR can request the ECB to provide its legal opinion, whenever the board might consider it beneficial for the accurate evaluation of the case at hand, without prejudice to the final autonomous assessment of the ABoR.

The last step of the procedure is the deliberation phase. In this phase the ABoR adopts an opinion and submits it to the Supervisory Board. The ABoR has to deliver its opinion within an appropriate time period, and no later than 2 months from the receipt of the request. The opinion is adopted by a majority of at least three members; the alternates do not take part in the deliberation. As anticipated above,

\footnotetext{
53 Art. 12 ABoR Decision.

54 Art. 14 ABoR Decision.

55 Art. 15 ABoR Decision.
} 
the opinion is not binding on the Supervisory Board and can only propose to either abrogate the contested decision, to replace it with a new decision of identical content, or to replace it with an amended one. ${ }^{56}$ However, one should not underestimate the influence that the opinion issued by the ABoR has on the Supervisory Board. Indeed, the latter has to "take into account' ${ }^{\prime 57}$ the opinion of the ABoR, meaning that when presenting the new draft decision to the Governing Council for the adoption under the non-objection procedure, the Supervisory Board will have to explain why it decided to follow or not follow the opinion. In the latter case, the Supervisory Board is subject to an enhanced motivation obligation. Moreover, by deciding not to follow the ABoR's opinion, if it were to suggest abrogating or amending the original decision, the Supervisory Board would accept a higher litigation risk in case an action is brought before the ECJ.

Lastly, the ABoR opinion is notified to the applicant only together with the new draft decision prepared by the Supervisory Board and adopted by the Governing Council. ${ }^{58}$ As already mentioned, the opinions of the ABoR are not public. Indeed, in the peculiar frame of the banking supervision, the confidentiality regime is also intended to protect the interests of the applicant in not having 'non-public' information on its financial situation or on its relationship with the supervisory authority disclosed.

It is not possible to file a request for review against the new decision. The applicant can only appeal it before the General Court within 2 months from its notification, in accordance with Article 263 TFEU. It is important to highlight that in such cases the initial ECB decision cannot be challenged before the Court since, following the ABoR opinion, it has been either repealed or replaced by a new ECB decision. Also, the ABoR opinion as such cannot be challenged before the Court; however, the arguments put forward by the ABoR will be disclosed in Court and the ECJ may take them into account within the judicial review process.

This means that, in principle, it is always possible to choose between the administrative way and the judicial one when opposing an ECB decision. However, after the ABoR has delivered its opinion and the Governing Council has adopted a new decision, the affected party can only pursue the judicial remedy. This way is not barred by time-limit requirements as the new period starts running after the new ECB decision replacing the first one is notified to the applicant.

\section{Issues and Challenges Faced by the ABoR}

\subsection{Overview of ABoR Experience}

The ABoR is a body established by the SSM Regulation to carry out an internal review of the ECB decisions in the supervisory field. It is a remedy, in addition to

\footnotetext{
56 Art. 16(2) ABoR Decision.

57 Art. 24(7) SSM Regulation.

58 Art. 24(9) SSM Regulation.
} 
the judicial one, that the legal system grants to persons affected by an ECB decision in the area of prudential supervision.

Compared to the judicial route, proceedings before the $\mathrm{ABoR}$ present some important advantages. First, the ABoR offers a qualified assessment of the case, as the review is carried out by persons with a particular knowledge and experience in the field of banking supervision. Moreover, proceedings before the administrative board are concluded in a short time, i.e. within maximum 2 months, and are less costly than proceedings before courts. ${ }^{59}$ Finally, the ABoR ensures the protection of confidential information whereas judicial proceedings are generally public.

The ABoR also serves to protect the interest of the public administration operating in full compliance with the law; its reviews may help avoid to see acts voided in court.

\subsection{Issues}

In its practice thus far, the $A B o R$ has had to deal with a number of issues. Notably, it was confronted with applications concerning the determination of the 'significance' of a supervised entity ${ }^{60}$ (which invariably requested to be labelled as 'less significant' and to remain under the supervisory umbrella of its national supervisor); issues of corporate governance ${ }^{61}$; the outcome of the Supervisory Review \& Evaluation Process (SREP), ${ }^{62}$ under which the competent authority reviews the arrangements, strategies, processes and mechanisms implemented by the supervised entity in order to comply with the requirements set out in the CRR and CRD IV and, as a result, may impose higher capital and liquidity requirements than statutorily prescribed in view of the riskiness of a bank's business, as well as other supervisory measures $^{63}$; the fit and proper assessment of members of the management body ${ }^{64}$; and withdrawals of the authorisation. ${ }^{65}$ As stated before, authorisation ${ }^{66}$ and withdrawal of authorisation is a Euro Area-wide competence of the ECB in respect of all credit institutions, as is the assessment of acquisition of qualifying holdings. ${ }^{67}$

\footnotetext{
59 See the Guide to the costs of the review. https://www.bankingsupervision.europa.eu/organisation/ governance/shared/pdf/abor_cost_guide/guidecostsreview.en.pdf. Accessed 24 April 2017.

${ }^{60}$ Which concern the delimitation between SIs and LSIs in Art. 6(4) SSM Regulation and the determination process set out in Arts. 39-71 SSM Framework Regulation.

61 For which Arts. 14 (fit and proper shareholders and authorisation requirement), 22-23 (assessment of qualifying holdings, including a transparent corporate structure) and 88-95 CRD IV are relevant.

62 Regulated in Art. 97-101 CRD IV.

63 See Arts. 102-104 CRD IV and Art. 16(2) of the SSM Regulation.

64 For which Art. 91 CRD IV provides the legal framework.

65 Arts. 18 and 67(2)(c) CRD IV, and Arts. 80-84 SSM Framework Regulation.

66 Arts. 4(a) and 14 SSM Regulation and Arts. 73-79 SSM Framework Regulation.

67 Arts. 4(c) and 15 SSM Regulation and Arts. 85-88 SSM Framework Regulation.
} 


\subsection{Challenges}

Among the challenges faced by the $\mathrm{ABoR}$ is the assessment of the correct application of national variations on implementing EU legislation by the ECB. As previously mentioned, the ECB is bound to apply national laws transposing EU directives and national legislations exercising options granted to the Member States in EU regulations. As the Single Rulebook consists of regulations and directives, the State legislator and NCAs may vary in their reading and application of EU prudential standards. This execution mode can be regarded as an original solution to the issue of the still highly fragmented supervisory legislation throughout Member States. ${ }^{68}$ At the same time, the uneven transposition of EU directives constitutes one of the major obstacles to the achievement of a genuine level playing field in the banking sector.

Although the ECB has undertaken steps towards a higher harmonisation, notably through the development of single methodologies, such as the one applied to the SREP, ${ }^{69}$ and via the adoption of binding legal acts, such as the ECB Regulation on the exercise of options and discretions available in Union law, ${ }^{70}$ there are still many relevant divergences among national laws and supervisory practices underpinning more or less stringent prudential approaches.

Against this background, this paper claims that diversity in national law represents a major challenge also for the ABoR. The latter, indeed, is constantly faced with the interpretation and the application of divergent national laws throughout its review procedures. This means that the legal standards against which the $\mathrm{ABoR}$ is called to assess the legality of the contested decision may vary depending on the State of establishment of the supervised entity concerned. Moreover, the ABoR may face a situation in which the applicable national law appears in contrast with EU law, thus raising the delicate question of which are the possible tools for the ABoR to address a potential mismatch between national and EU law.

On the basis of the ABoR experience as well as from an academic perspective, two issues may be highlighted as giving rise to the most pressing concerns in this respect: (1) the assessment of the suitability of the members of management bodies and (2) the supervision of bank holding companies. As will be shown below, these two issues are deemed to be ripe for legislative action.

\subsubsection{Fit and Proper Assessment}

Pursuant to Article 4(1)(e) of the SSM Regulation, the fit and proper (FAP) assessment of the persons responsible for the management of credit institution is now to be considered as part of the ECB's task of ensuring compliance with the

\footnotetext{
68 On the application of national legislation by the ECB, see Witte (2014), pp 89 et seq.; Magliari (2015), pp 1349 et seq.

69 See https://www.bankingsupervision.europa.eu/ecb/pub/pdf/srep_methodology_booklet_2016.en.pdf (accessed 24 April 2017).

70 Regulation (EU) 2016/445 of the European Central Bank of 14 March 2016 on the exercise of options and discretions available in Union law (ECB/2016/4), OJ L 78/60, 24 March 2016.
} 
governance requirements by credit institutions. The ECB is therefore the competent authority in charge of taking decisions regarding the suitability of the members of the management bodies of significant credit institutions in the SSM perimeter. ${ }^{71}$

Under the CRD IV, both executive and non-executive directors of banks, ${ }^{72}$ and of bank holding companies, ${ }^{73}$ need to be assessed by the supervisory authorities against a number of substantive criteria. The ECB's Draft Guide to FAP assessment mentions five criteria: experience; reputation; conflicts of interest and independence of mind; time commitment; and collective suitability. ${ }^{74}$ Knowledge and experience are one element, reputation is another one. 'Sufficiently good repute and [...] sufficient knowledge, skills and experience' is how the CRD IV describes the requirements. ${ }^{75}$ To these requirements it adds a number of further standards, such as range of experiences and diversity in the board (collective suitability), sufficient time to devote to board membership, and 'honesty, integrity and independence of mind' to assess and challenge senior management decisions. Furthermore, members of the management body should be provided with adequate training, an element which the supervisor may take up when someone is proposed whose background is as of yet insufficient in expertise. ${ }^{76}$ If these standards are not met at inception, no banking authorisation is to be given. ${ }^{77}$ The FAP criteria need constant observance: the CRD IV provides for supervisory measures and administrative sanctions if directors do not meet these criteria on an on-going basis. ${ }^{78}$ Notably, the bank's authorisation may be revoked ${ }^{79}$ and the supervisor may make a public statement on non-compliance, ${ }^{80}$ impose pecuniary sanctions ${ }^{81}$ and temporarily ban a credit institution's director or another natural person from exercising functions in a bank. ${ }^{82}$ However, the fit and proper assessment of directors is exercised in notably varied manners across Member States. On the basis of limited research into a few

\footnotetext{
71 See Finesi (2015), pp 45-78.

72 Arts. 88-91 CRD IV.

73 Art. 121 CRD IV.

74 Draft guide to fit and proper assessments, available at https://www.bankingsupervision.europa.eu/ legalframework/publiccons/pdf/fap/fap_guide.en.pdf?723db13839d47e0800b8c930a641893f (accessed 24 April 2017).

75 Art. 91(1) CRD IV.

76 Art. 91(9) CRD IV. See pp 10, 12 and 26 of the ECB's recent Draft Guide to FAP assessment for how the ECB takes training into account.

77 Art. 13(1) CRD IV.

78 Arts. 18(c) and Art. 67(2)(c) CRD IV.

79 Art.67(1)(p) CRD IV.

80 Art.67(2)(a) CRD IV.

81 Art.67(2)(e)-(g) CRD IV.

82 Art. 67(2)(d) CRD IV. Such a ban may also be applied to remove the unwanted director from exercising his or her functions until he or she has been considered fit and proper or, more likely, has been replaced by someone the supervisory authority does approve.
} 
jurisdictions only, ${ }^{83}$ relevant differences can be observed in the assessment of the suitability of bank directors and senior management as 'fit and proper'.

The differences observed relate to national supervisory practices of FAP testing. In particular, many divergences have been identified in supervisory policies and processes, as well as in the transposition of the substantive fit and proper requirements. Some NCAs accept appointments of directors and assess ex post whether they are suitable, others insist on prior vetting by the competent authority. In some Member States, allowing an ex post assessment, the verification of fit and proper requirements has to be performed before the appointee can be registered and take up the appointment; in others the appointed members can immediately start performing their functions. Furthermore, in a number of Member States the competent authority can raise an objection to the appointment only within a given time period whereas, in others, there is no legal deadline for the rejection of the appointee.

Informal procedures, entailing a pre-screening of the candidates, may apply which, in the Netherlands, have been criticised as leaving the candidate without recourse if the credit institution withdraws the application for an informal FAP test once the supervisor has expressed disapproval. Also in the Netherlands, an external review of the process of assessing the fit and proper nature of directors by the prudential authority ${ }^{84}$ and conduct-of-business authority ${ }^{85}$ was carried out in the second half of $2016 .^{86}$ Its findings ${ }^{87}$ were submitted to the Dutch parliament, ${ }^{88}$ together with the response of the two authorities. The review found that the process of assessment was generally adequate in terms of the statutory requirements but could be improved. The transparency of the assessment vis-à-vis the prospective candidates may be improved (the criteria applied; the process followed), while assessment against other criteria than financial expertise may be relevant for boardroom diversity. A candidate's position was considered precarious ('very vulnerable'), with the relationship between the supervisors and the financial institutions embedded in administrative law, whereas the candidate, whose reputation is at stake, is not formally involved. Negative results of assessments

\footnotetext{
83 The NCAs of the United Kingdom, Luxembourg and the Netherlands insist on prior assessment whereas, apparently, in France, Italy, Germany, Austria and Greece, an ex post assessment seems to be accepted, implying that a board member or senior executive functions without the supervisory authority having pronounced on his or her suitability under the fit and proper criteria. This may be considered at variance with the CRD IV which makes supervisory agreement on the suitability of directors an authorisation requirement.

${ }^{84}$ The Dutch central bank, and the competent authority: De Nederlandsche Bank (DNB), see https:// www.dnb.nl/en/home/index.jsp (accessed 24 April 2017).

85 The Autoriteit Financiële Markten (AFM). See https://www.afm.nl/en (accessed 24 April 2017).

${ }^{86}$ See press release of DNB, http://www.dnb.nl/nieuws/nieuwsoverzicht-en-archief/persberichten-2016/ dnb350200.jsp (accessed 24 April 2017).

${ }^{87}$ Rapportage Externe evaluatie toetsingsproces AFM en DNB (Reporting on the external evaluation of the assessment process of DNB and AFM) by the committee headed by Professor Annetje Ottow, available at http://www.dnb.nl/binaries/Eindrapport\%20commissie\%20Ottow_tcm46-350199.pdf (accessed 24 April 2017).

${ }^{88}$ See https://www.tweedekamer.nl//kamerstukken/brieven_regering/detail $: i d=2016 Z 23873 \& d i d=$ 2016D48855 (accessed 24 April 2017).
} 
should be given in writing, instead of orally. The interaction between FAP assessment and on-going supervision was also a matter of concern. ${ }^{89}$ In the context of the SSM, the review report remarks that there are "various national surveillance systems' which include, 'in addition to the ex-ante system like the Dutch system, an ex-post evaluation system in most [Member States]'.

On its Banking Supervision website, the ECB deplores the lack of uniformity of FAP assessment across Europe and argues for this element to be included in the update of the CRD IV, after the CRR and CRD IV review which closed early October 2016. ${ }^{90}$ This is a call we wholeheartedly subscribe to. On 23 November 2016, the Commission published a package containing proposed amendments to the capital requirement directive and regulation. ${ }^{91}$ However, no reference is currently made to an amendment of the FAP assessment and the substantive fit and proper requirements remain subject to the minimum harmonisation provisions set out in the CRD IV.

In the meanwhile, the ECB has recently launched a public consultation on a draft guide to fit and proper assessment, ${ }^{92}$ a non-binding document aiming at harmonising the supervisory practice in the assessment of the substantial criteria laid down in the binding national law implementing Article 91 of the CRD IV. The EBA and ESMA are currently consulting on guidelines on the assessment of the suitability of directors and senior management. ${ }^{93}$

\subsubsection{Bank Holding Company Supervision}

Bank holding companies (BHCs) are considered supervised entities ${ }^{94}$ to be included in the supervisory reach of the ECB, though they are named differently. Financial Holding Companies (FHCs) ${ }^{95}$ and Mixed Financial Holding Companies

\footnotetext{
89 See also, Principle 6 of the ECB's Draft Guide to Fit and Proper Assessments.

90 See https://www.bankingsupervision.europa.eu/about/ssmexplained/html/fap.en.html (accessed 24 April 2017). 'We would therefore like to see the fit and proper process become part of the revision and update of CRD IV so that the same rules are applied throughout Europe'.

91 See http://ec.europa.eu/finance/bank/regcapital/crr-crd-review/index_en.htm (accessed 24 April 2017).

92 See https://www.bankingsupervision.europa.eu/legalframework/publiccons/pdf/fap/fap_guide.en. pdf?723db13839d47e0800b8c930a641893f (accessed 24 April 2017).

93 See draft Guidelines on the Assessment of the Suitability of the Members of Management Body and Key Function Holders, available at https://www.eba.europa.eu/documents/10180/1639842/ Consultation+Paper+on+Joint+ESMA+EBA+Guidelines+on+suitability +of + management+body+ \%28EBA-CP-2016-17\%29.pdf (accessed 24 April 2017).

94 Art. 2(20) SSM Framework Regulation.

95 See Arts. 4(1) (20), (30) and (31) CRR which define the concept as follows. A 'financial holding company' means a financial institution, the subsidiaries of which are exclusively or mainly institutions or financial institutions, at least one of such subsidiaries being an institution, and which is not a mixed financial holding company; 'parent financial holding company in a Member State' refers to a FHC in a Member State that is not a subsidiary of a bank or investment firm authorised in the same State, or a subsidiary of a holding company set up in this State. An 'EU parent financial holding company' is a parent FHC that is not a subsidiary of a bank or investment firm authorised anywhere in the EU, or of a holding company set up anywhere in the EU.
} 
$(\mathrm{MFHCs})^{96}$ are subject to a whole range of standards in the context of consolidated supervision. Dominant supervisory practices in the EU thus far seem to address the licensed bank when consolidated supervision requirements are at issue, ${ }^{97}$ rather than the (M)FHCs directly. Several Member States go beyond this and require BHCs to be authorised and to report directly to the supervisory authorities. ${ }^{98}$ BHCs are to comply with consolidated requirements and to ensure compliance by group members. Other Member States rely solely on implementing the relevant provisions of the CRR, CRD IV and FICOD. None of these three legal acts requires bank holding companies to register and be authorised, whereas certain national laws do require the (M)FHCs as such to be supervised.

An approach which does not fully include (M)FHCs in the scope of supervision as addressees of prudential requirements and as the agencies within a financial group that need to ensure compliance with supervisory norms by the entire group is, we submit, flawed. Since the presentation was given upon which this publication rests, the European Commission has adopted proposed changes to correct the current approach. ${ }^{99}$ However, even now, under the legal provisions currently

\footnotetext{
96 See Arts. 4(1) (21), (32) and (33) CRR. Succinctly, an MFHC is a parent undertaking of a financial conglomerate that itself is not a supervised financial sector company (bank, insurance undertaking, investment firm, asset management company, or alternative investment fund manager). The definition of a financial conglomerate includes a group with significant financial business that extends into both the banking and insurance sectors with a non-regulated entity at its head. See Art. 2(14) and (15) of the Financial Conglomerates Directive or FICOD: Directive 2002/87/EC of the European Parliament and of the Council of 16 December 2002 on the supplementary supervision of credit institutions, insurance undertakings and investment firms in a financial conglomerate and amending Council Directives 73/239/ EEC, 79/267/EEC, 92/49/EEC, 92/96/EEC, 93/6/EEC and 93/22/EEC, and Directives 98/78/EC and 2000/12/EC of the European Parliament and of the Council, OJ L 35/1, 11 February 2003, as amended, lastly by CRD IV; consolidated version (Document 02002L0087-20130717), available at http://eur-lex. europa.eu/legal-content/EN/TXT/?uri=CELEX:02002L0087-20130717 (accessed 24 April 2017).

97 See the Commission answer's in Q\&As, EBA Q\&A 2013/521, available at http://www.eba.europa.eu/ single-rule-book-qa/-/qna/view/publicId/2013_521 (accessed 24 April 2017). The language on prudential consolidation in Art. 11 CRR leads the European Commission, in an answer on the website of the EBA, to conclude that the authorised institutions need to abide by the requirements of consolidated supervision incumbent on the group, including their parents. Thus, it would seem that only authorised banks are addressees of supervisory decisions. Whether this also means that the level of capital to be maintained on a consolidated level in the group needs not necessarily be held at the parent, is unclear. An adequate protection of depositors and the taxpayer is achieved only when the ultimate parent holds sufficient capital in relation to the group's needs, i.e. at the level which the supervisory standards for consolidated supervision prescribe.

98 Notably, Art. L 517-5 of the French Code Monétaire et Financier, and the sections of this code referred to there, available at https://www.legifrance.gouv.fr (accessed 24 April 2017). Section 10 of the German Gesetz über das Kreditwesen, available at https://www.bafin.de/SharedDocs/Downloads/EN/ Aufsichtsrecht/dl_kwg_en.pdf?_blob=publicationFile (accessed 24 April 2017). Sections 61 and 67 of the Testo Unico Bancario Decreto legislativo $1^{\circ}$ settembre 1993, $n .385$ (Italian Consolidated Law on Banking-Legislative Decree 385/1993), available at https:/www.bancaditalia.it/compiti/vigilanza/ intermediari/Testo-Unico-Bancario.pdf (accessed 24 April 2017). Sections 40, 50 and 56 of the Spanish Ley 10/2014, de 26 de junio, de ordenación, supervisión y solvencia de entidades de crédito (Act of 26 June 2014 on the supervision of credit institutions); and Section 250 of Belgium's Bankwet/Loi bancaire (Law on the legal status and supervision of credit institutions), 25 April 2014, available at http://www. ejustice.just.fgov.be/cgi_loi/change_lg.pl?language=fr\&la=F\&cn=2014042508\&table_name=loi and https://www.nbb.be/doc/cp/moniteur/2015/20151124_law25april2014en.pdf (both accessed at 24 April 2017).

99 http://ec.europa.eu/finance/bank/regcapital/crr-crd-review/index_en.htm (accessed 24 April 2017).
} 
applicable, one may argue that (M)FHCs are to be treated as addressees of norms and need to ensure compliance with consolidated standards by the entire group. This is in line with more recent legal acts, such as Directive 2014/59/EU (the BRRD), which allows for resolution tools to be used for financial holding companies and mixed financial holding companies, and the SSM Regulation, as well as with our reading of legislative intentions and, crucially, with business practice. Such a broader reading of the current supervisory law is also in line with the approach followed in many Member States. It is in fact the parent that directs the functioning of the group, not the other way around. A joint approach to BHCs is called for, which holds (M)FHCs accountable for adequacy of capital, liquidity provisioning, risk management and supervisory relationships, and treats them as if they are subject to authorisation. Treating BHCs as core entities in the supervision of banking groups is also crucial for the single point of entry of the resolution of a banking group.

The Commission's proposed amendment to the CRD IV and CRR ${ }^{100}$ modifies several Articles in order to bring financial holding companies and mixed financial holding companies directly within the scope of the EU prudential framework. In particular, 'an authorisation requirement is introduced along with direct supervisory powers over financial holding companies and mixed financial holding companies (Article $21 \mathrm{a}$ of the CRD). Article 11 of the CRR is amended to clarify that-where requirements are applied on a consolidated basis at the level of such holding companies - it will be the holding company which is directly responsible for compliance, not the institutions that are subsidiaries of such holdings. Articles 13 and 18 of the CRR are adjusted to reflect direct responsibility of the financial holding companies or mixed financial holding companies'. ${ }^{101}$

Such proposed amendments provide a welcome opportunity to bring Europe in line with decades long law and practice across the Atlantic ${ }^{102}$ and with several African prudential regulations which unequivocally subject bank holding companies to authorisation and make clear that they need to abide by capital and other prudential standards. ${ }^{103}$ Looking south, rather than (only) westwards, is what Europe may fruitfully do here.

\footnotetext{
100 See, in particular, Recital 4 of the Commission' s Proposal for a Directive of the European Parliament and of the Council amending Directive 2013/36/EU, which recognises that it is necessary that the prudential authorisation and supervision of the financial holding companies and mixed financial holding companies should also be given to the consolidating supervisor. The European Central Bank, when performing its task to carry out supervision on a consolidated basis over credit institutions' parents pursuant to Art. 4(1)(g) of Council Regulation (EU) No. 1024/201311 should also be responsible for the authorisation and supervision of financial holding companies and mixed financial holding companies'. See also the proposed amended Art. 1 of the CRR stating that 'This Regulation lays down uniform rules concerning general prudential requirements that institutions, financial holding companies and mixed financial holding companies supervised under Directive 2013/36/EU shall comply with'.

101 Commission's Proposal for a Directive amending Directive 2013/36/EU, Explanatory Memorandum, p 12. See http://ec.europa.eu/finance/bank/regcapital/crr-crd-review/index_en.htm (accessed 24 April 2017).

102 Where the United States has extensive legislation: the Bank Holding Company Act of 1956, 12 USC $\S 1841$ et seq., available at https://www.law.cornell.edu/uscode/text/12/chapter-17 (accessed 24 April 2017). See also the Bank Holding Company Supervision Manual, available at https://www.federalreserve. gov/publications/files/bhc.pdf.

103 See Taylor and Smits (2016).
} 


\section{Outlook}

One may expect the role of $\mathrm{ABoR}$ to continue: as a fast, cheap and expert first route to challenge prudential decisions adopted by the ECB. Although there are cases pending before the European Courts in this area that have not previously been the subject of an ABoR review, wider experience with the review process may lead to more cases coming before the ABoR. How the interplay between administrative review and judicial proceedings evolves will be an area of acute interest, to the supervised entities, to the supervisors and the panels and courts involved, and to academics. The various review channels in the financial sector we have discussed all serve to protect the rule of law in an area of acute importance to the economic and social well-being of the people of Europe.

Open Access This article is distributed under the terms of the Creative Commons Attribution 4.0 International License (http://creativecommons.org/licenses/by/4.0/), which permits unrestricted use, distribution, and reproduction in any medium, provided you give appropriate credit to the original author(s) and the source, provide a link to the Creative Commons license, and indicate if changes were made.

\section{References}

Arons TMC (2015) Judicial protection of supervised credit institutions in the European Banking Union. In: Busch D, Ferrarini G (eds) European Banking Union. Oxford University Press, Oxford, pp 433-473

Babis V (2015) Single rulebook for prudential regulation of banks: mission accomplished? Eur Bus Law Rev 26:779-803

Blair W (2013) Board of appeal of the European supervisory authorities. Eur Bus Law Rev 24:165-171

Bolzonello L (2016) Independent administrative review within the structure of remedies under the treaties: the case of the Board of Appeal of the European Chemicals Agency. Eur Public Law 22:569-581

Brescia Morra C (2014) From the Single Supervisory Mechanism to the Banking Union. The role of the ECB and the EBA. Studi sull'integrazione europea 3:465-484

Brescia Morra C (2016) The administrative and judicial review of decisions of the ECB in the supervisory field. AaVv Scritti sull'Unione Bancaria, Quaderni di Ricerca Giuridica della Banca d'Italia no 81, pp 109-132

Bronckers M, Van Gerven Y (2009) Legal remedies under the EC's new chemical legislation REACH: testing a new model of european governance. Common Market Law Rev 46(6):1823-1871

Busch D, Ferrarini G (eds) (2015) European Banking Union. Oxford University Press, Oxford

Chirulli P, De Lucia L (2015) Specialized adjudication in EU administrative law: the boards of appeal of EU agencies. Eur Law Rev 40:832-857

Chiti E, Vesperini G (eds) (2015) The administrative architecture of financial integration. Institutional design, legal issues, perspectives. Il Mulino, Bologna

D'Ambrosio R (2015) The ECB and NCAs liability within the SSM. Quaderni di Ricerca Giuridica della Consulenza Legale della Banca d'Italia no 78

De Lucia L (2014) The microphysics of European administrative law: administrative remedies in the EU after Lisbon. Eur Public Law 20:277-307

Ferran E, Babis V (2013) The European single supervisory mechanism. Legal Studies Research Paper Series, paper no 10/2013. University of Cambridge

Finesi S (2015) Suitability of bank directors in Europe: just a matter of being 'fit \& proper'? Eur Co Financ Law Rev 12:45-78

Gortsos CV (2015) The Single Supervisory Mechanism (SSM): legal aspects of the first pillar of the European Banking Union. Nomiki Bibliothiki-European Public Law Organisation (EPLO), Athens 
Kalintiri A (2016) What's in a name? The marginal standard of review of 'complex economic assessments' in EU competition enforcement. Common Market Law Rev 53:1283-1316

Lackhoff K, Meissner M (2015) Contesting decisions in the Single Supervisory Mechanism: what banks must observe for a proceeding at the Administrative Board of Review. J Int Bank Law Regul 30:285-295

Lamandini M (2014) The ESAs' board of appeal as a blueprint for the quasi-judicial review of European financial supervision. Eur Co Law 11:290-294

Lamandini M et al (2015) Depicting the limits to the SSM's supervisory power: the role of constitutional mandates and of fundamental rights protection. Quaderni di Ricerca Giuridica della Consulenza Legale della Banca d'Italia no 79

Lastra RM (2012) Evolution of the European Central Bank. Fordham Int Law J 35:1260-1281

Lefterov A (2015) The single rulebook: legal issues and relevance in the SSM context. ECB Legal Working Paper Series no 15

Lo Schiavo G (2014) From national banking supervision to a centralized model of prudential supervision in Europe? The stability function of the Single Supervisory Mechanism. Maastricht J Eur Comp Law $21: 110-140$

Loosveld S (2013) Appeals against decisions of the European supervisory authorities. J Int Bank Law Regul 28:9-13

Magiera S, Weiß W (2014) Alternative dispute resolution mechanisms in the European Union law. In: Dragos DC, Neamtu B (eds) Alternative dispute resolution in European administrative law. Springer, Heidelberg, pp 489-536

Magliari A (2015) Il Single Supervisory Mechanism e l'applicazione dei diritti nazionali da parte della Banca centrale europea. Riv italiana dir pubbl comunit 5:1349-1380

Navin-Jones M (2015) A legal review of EU boards of appeal in particular the European Chemicals Agency Board of Appeal. Eur Public Law 21:143-168

Smits R (2005) The role of the ESCB in banking supervision. Legal aspects of the European central banks. Liber Amicorum of Paolo Zamboni Garavelli. European Central Bank, Frankfurt, pp 199-212

Taylor J, Smits R (2016) Bank holding company regulation in Kenya, Nigeria and South Africa: a comparative inventory and a call for Pan-African regulation. https://papers.ssrn.com/sol3/papers. cfm?abstract_id=2881819. Accessed 24 April 2017

Teixeira PG (2014) Europeanising prudential banking supervision. Legal foundations and implications for European integration. In: Fossum JE, Menendez AJ (eds) The European Union in crises or the European Union as crises? Arena Report no 2/14, pp 527-583

Ter Kuile G et al (2015) Tailor-made accountability within the Single Supervisory Mechanism. Common Market Law Rev 52:155-190

Witte A (2014) The application of national banking supervision law by the ECB: three parallel modes of executing EU law. Maastricht J Eur Comp Law 21:89-109

Witte A (2015) Standing and judicial review in the new EU financial markets architecture. J Financ Regul $1: 1-37$

Wymeersch E (2012) The European Financial Supervisory Authorities or ESAs. In: Wymeersch E et al (eds) Financial regulation and supervision. A post-crisis analysis. Oxford University Press, Oxford, pp 232-317

Wymeersch E (2014) The Single Supervisory Mechanism or 'SSM', part one of the Banking Union. Financial Law Institute, Universiteit Gent, Working Paper 1

Concetta Brescia Morra is Vice Chair of ABoR; Associate Professor of Economic Law at the University of Sannio, Benevento, Faculty of Law; and Adjunct professor of Financial Market Regulation at the Libera Università Internazionale degli Studi Sociali (LUISS)—Guido Carli, Rome.

René Smits is Alternate Member of ABoR; Professor of the Law of the Economic and Monetary Union (EMU), University of Amsterdam; and consultant on EMU law and banking regulation.

Andrea Magliari is Postdoctoral researcher in Administrative Law at the University of Trento. He has been a trainee at the Secretariat to the Supervisory Board at the ECB. 